\title{
A PIONEERING THEORY OF INFORMATION STRUCTURE*
}

\author{
KATALIN É. KISS \\ Research Institute for Linguistics \\ Hungarian Academy of Sciences \\ Benczúr utca 33. \\ H-1068 Budapest \\ Hungary \\ ekiss@nytud.hu
}

\begin{abstract}
The paper deals with Samuel Brassai, a 19th-century Hungarian linguist and polyhistor, who was the first in the world to discover the role of information structure in the syntactic organization of the sentence. Preparing to describe Hungarian syntax, he first wanted to establish the universal and typical characteristics of the sentence on the basis of a number of genetically unrelated languages. The universal structure he identified is essentially the topic-comment structure (called inchoativum-bulk articulation by him). French-type languages realize a constrained version of this universal structure, requiring the topicalization of the grammatical subject. In Hungarian, the initial position of the comment is a focus (in his terminology: attribute) position. His Hungarian sentence model is a forerunner of today's generative sentence structure.
\end{abstract}

Keywords: information structure, topic, focus, typology, Hungarian syntax

\section{Introduction}

This article aims to call attention to the fact that the idea of the so-called communicative sentence articulation, or information structure, first appeared in the sentence theory of a 19th-century Hungarian linguist, Sámuel Brassai (1797-1897). The syntactic theory of Brassai, unknown abroad and forgotten in Hungary, deserves to be reviewed not only because of its historical interest - although the general belief that it was

* This is a revised version of a paper published in Hungarian Linguistics, ed. by Ferenc Kiefer, 1982, John Benjamins, Amsterdam \& New York, pp. 331-50. 
Georg von der Gabelentz who discovered communicative sentence articulation has to be rectified - but also because of the current relevance of its results. ${ }^{1}$

As will be shown, Brassai's ingenious universal framework of sentence description rendered it possible for him to outline the only Hungarian syntax until the nineteen eighties that does not content itself with stating that Hungarian is a free word order language, but provides rules for the synthesis, i.e., the generation, of Hungarian sentences.

Brassai had pioneering ideas in other areas of linguistics, as well, e.g., in the methodology of foreign language teaching. His German textbook (Brassai 1855) was ahead of his time by a hundred years in several respects: it regarded the sentence as the basic unit of language teaching; the rules were to be formulated by the students on the basis of the teacher's examples; teaching proceeded gradually from the simplest constructions to the most complex ones; the principle of "one at a time" was adopted; repetition and conversation represented constant elements of the teaching process, etc.

Brassai's position concerning the language reform that took place in Hungary in the first half of the 19th century also still counts as up-to-date. He argued vehemently that Hungarian did not need to be beautified, or enriched; in fact, there are no ugly, or poor languages. Every language is equally suitable for the communication of ideas and for the naming of the phenomena of the world. At the same time, the creation of new words for the denomination of new notions is an acceptable practice, as it is part of the natural operation of languages - provided the new words have been coined by the regular means of word formation.

Despite their originality, most of Brassai's ideas soon sank into oblivion - which can be attributed to various facts. Abroad, they necessarily remained unknown since they were published in Hungarian. As for Hungary, his ideas may have been too new to fit into the system of linguistic thought of the day. Besides, Brassai, a professor of mathematics, an active researcher of botany and several other branches of natural science, an expert in Sanskrit, fluent in eight languages, a musicologist and an excellent violinist, an author of studies on philosophy, logic, aesthetics, economics, etc., was looked upon not so much as a linguist but as a

1 The Prague School, e.g., Mathesius (1939), traces back the idea of functional sentence perspective to Henri Weil (1844), who briefly discusses the contextual role of word order (Weil 1844, 25-6). For a discussion of Weil's work, see Kiefer (2005). 
polyhistor, so his linguistic theory may simply not have been considered seriously enough by his contemporaries. His colorful personality may also have contributed to the image of his not being a very deep thinker. However, it might well be the case that the secret of his originality, of his being ahead of his time by a century, lay precisely in his "amateurish" status; he was not influenced by preconceptions and prejudices.

\section{Brassai's concept of language description}

Brassai first formulated his grammatical theory in a lecture entitled $T a$ pogatódzások a magyar nyelv körül [Exploring the Hungarian language] held at the Hungarian Academy of Sciences (1852), but the most complete elaboration of it was his study A magyar mondat [The Hungarian sentence] published between 1860-1865 (Brassai 1860; 1863-1865).

In the middle of the 19th century, when the basic unit of both comparative and descriptive linguistic research was the word, when-according to a saying attributed to Jakob Grimm - syntax came only half way within the notion of grammar - it was considered a novelty, ahead of the time, that Brassai put the sentence into the focus of his investigations concerning the rules of Hungarian. "The characteristics of a language dwell in the characteristics of the sentence", he wrote $(1860,304)$, so not only descriptive research but also historical and comparative investigation should center on syntax. Language teaching, too, can only be efficient if it is based on sentences instead of words.

The methodology and structure of Brassai's argumentation also contain some remarkably modern elements (especially in Brassai 1860, 18631865). Brassai considers linguistics a natural science, the task of which is to set up laws and systems inductively, through the observation of linguistic facts, and to deduce the description of empirical phenomena from these laws and systems - just as it happens in physics or botany. Accordingly, when he sets out to describe the Hungarian sentence, he first establishes the universal and typical characteristics of the sentence as such on the basis of such remote languages as French, Classical Greek, Hebrew, Tibetan, Turkish, and Hungarian, and then, in the second part of the study, he analyzes the Hungarian language from the point of view of the syntactic aspects which have turned out to be universally relevant, and on the basis of the sentence pattern which has proved to be universally valid. 
The first part of the study, contrasting languages of various origin from a syntactic point of view, is actually an early example of typological research. Brassai himself was aware of its novelty: "I have outlined a new, syntactic type of language comparison", he wrote. "The individual syntactic features or groups of them often indicate linguistic relationships which are quite different from the etymological ones. Saying this, I by no means wish to underrate the importance of the latter, neither do I wish the solid results gained from the latter to be discarded for the former [...]. As etymology establishes the notion of physical relationships, syntax establishes that of spiritual relationships" (1860, 397-8).

\section{Brassai's notion of syntax}

Looking for the universal characteristics of the sentence, Brassai comes to the conclusion that the sentence-except for the type of sentences containing a copula and expressing a logical judgement - is not built on the dichotomy of the subject and the predicate, but only has a single supporting pillar: the verb. Linguists assign to the subject such an outstanding role only under the influence of logic, by analogy with logical judgements, and also because they base their supposedly universal statements on the little group of Indo-European languages of Western Europe. If the subject is, indeed, an indispensable basic unit of the sentence, why can it so often be omitted e.g., in Hungarian or Latin? Actually there is no linguistic interpretation of the subject by means of which it could be determined in every sentence. If we regard the part of the sentence about which the predicate is asserted as the subject, then the dative is to be identified as the subject in the following sentence:

(1) Ennek a falunak csökken a lakossága.

this-dat the village-dat decreases the population-poss.3sg

'Of this village, the population is decreasing.'

If the subject is defined as the noun in the nominative, it cannot be distinguished from the object e.g., in English and in French, i.e., in languages with no declension. For these languages, it would not be sufficient to define the subject as the noun at the head of the sentence, either, since this would only make the analysis of sentences possible, but not the synthesis of them, as we would not know which word is to be put into sentenceinitial position. The definition of the subject as that which acts in the 
case of an active verb, which is acted upon in the case of a passive verb, and which is in a given state or to which something happens in the case of a middle verb, would not be of much use, either, since e.g., in Tibetan the actor of a transitive verb is in the instrumental. If the subjects of diverse languages had common semantic or conceptual features, it could not happen that what is the subject in one language (Ich habe) is expressed by a dative in another (Hungarian nekem van 'to me is'). These facts indicate that instead of forcing the term 'subject', borrowed from logic, on the syntactic structure of sentences, it is better simply to speak about the nominative complement, and there is no reason not to consider the nominative to be of the same rank as the other complements of the verb.

Semantic considerations also lead Brassai to believe that the central and most important constituent of sentence structure is the verb and only the verb. Language was born for the coordination of collective human activities, and serves primarily for the denomination of events, actions, happenings, so it is the verb, expressing the action or happening, that must play the central role in it. The case-marked nouns and adverbs are merely subordinate complements (in Brassai's terminology, determiners) of the verb, since they only "support it; explicate, explain, expand, restrict its meaning; denote circumstances belonging to it" (1863-1865, 185) - Brassai claims, anticipating such 20th century linguistic theories as e.g., Fillmore (1968).

Naturally, the assumed universal, "deep" sentence structure, consisting of a verb and its complements, has various realizations in the different languages. The characterization of the sentence structure of a given language must specify at least the following aspects:

- The quality of complements, i.e., the presence or lack, and the distribution of case-marked, prepositional and postpositional nouns.

- The number of the different kinds of complements.

- Word order, including both the order of the complements and the verb, and the internal order of the complex complements. (A novelty, since word order was very much neglected in the syntactic descriptions of the day.)

- The use (or absence) of the copula.

- The quality and number of tenses and moods. (Brassai sets up an abstract tense system, and examines which concepts of this system are marked in the given language.)

- The syntax and function of the various non-finite verb forms. 
- The system of pronouns; pronouns appearing as clitics and agreement suffixes; the (im)possibility of pronoun-drop.

- The presence or lack of an article, and its position relative to the noun.

- The use of conjunctions; the distribution of coordination and subordination.

- The distribution of agreement.

- Agglutination versus flection.

- The role of prosody in syntax.

etc.

\section{Brassai's universal sentence structure}

Of the chapter investigating the universal and typical features of the sentence, it is the section dealing with word order that contains the most ingeniously novel ideas, some of which are revelations even today. Seeking an answer to the question whether there is some common feature which may be generalized inductively in the different sentence types of the known languages, Brassai reaches a positive conclusion. Both fixed and free word order languages display a sentence structure which begins with one or more complements carrying already known information. These complements "practically lay a basis for the meaning of the sentence in the listener's mind, i.e., they are calling attention, and pointing forward, connecting the mental activity of the listener with that of the speaker" $(1860,341)$. He calls this initial part of the sentence subject in a different sense of the word (Brassai 1852), inchoativum (1860; 18631865), introduction (1874), finally, preparatory part (1885). The second part of the sentence, including the verb, is the predicate (1852), or bulk (Hungarian zöm) $(1860 ; 1863-1865)$, or message (1874), or principal part (1885). The function of this second part is "the communication of an action, or a circumstance of an action that the speaker supposes to be unknown to the listener" $(1874,72)$. Besides the new ideas, the known ones that are not set off as an introduction are also to be found in the bulk. The bulk, which is more important than the inchoativum by virtue of its informative value, is present in every sentence; the inchoativum, on the other hand, may also be missing. It can be omitted (i) if the speaker does not think it necessary to prepare the listener for the comprehension 
of the bulk; or (ii) if the preparatory idea has been implicitly or explicitly included in the preceding text; or (iii) if the speaker is in such a hurry to communicate his message that he forgets to prepare the listener for it. So not every sentence initial constituent is an inchoativum; it can also have an emphasizing role, as is attested e.g., in French in the case of a fronted vainment, en vain, à peine, souvent, or rarement.

The sentence structure consisting of an inchoativum and a bulk seems to be a universal characteristic of languages. Which complements can serve as an inchoativum, on the other hand, is specific to a given language. For instance, in the Semitic languages and in Hungarian every kind of complement can function as an inchoativum, while in the Romance languages the inchoativum is usually the nominative. In German the inchoativum always consists of a single complement, while in Hungarian it can also consist of two or more complements. It might also be characteristic of a language if its sentences neccessarily, often, or rarely begin with an inchoativum.

\section{Brassai versus Gabelentz}

It is a general surmise in linguistics that the first intuition concerning this kind of "communicative" sentence structure, or information structure appeared in a study of Henri Weil in 1844; while the first elaboration of the idea as well as the introduction of the terms psychological subject and psychological predicate are due to Georg von der Gabelentz $(1869 ; 1875)$. Brassai came to know the articles of Gabelentz, and he dedicated a whole study to showing that Gabelentz's theory is not only later than his own, but is also inferior to it in terms of both clarity and coherence (Brassai 1885). Gabelentz could not cut himself completely free from the traditional subject-predicate articulation of logical origin. For instance, he defined the psychological subject as that "about which we assert something", although this definition does not in the least suit the initial element of the following sentence:

(2) Tegnapelőtt láttam egy legénykét az utcán.

the.day.before.yesterday saw-I a lad-acc the street-on

'The day before yesterday, I saw a lad in the street.'

Brassai raises the following major objections to Gabelentz's theory: 
(i) Gabelentz does not answer the question whether the psychological subject and psychological predicate are equally indispensable or whether one of them can be omitted in certain cases. In Brassai's study (1860; 1863-1865), on the other hand, it is clear that only the bulk is a fundamental part of the sentence; the inchoativum is less important and can also be missing.

(ii) Gabelentz does not say whether or not there is a dividing line between the psychological subject and the predicate, and if there is a dividing line, how it is realized in the various languages. From Brassai's study, on the other hand, we learn that the two parts are separated from one another by means specific to a given language; e.g., in Hungarian the division is indicated by the sentence stress on the first syllable of the bulk, while in French and German, it is marked by the word order.

(iii) Gabelentz does not clearly specify the defining features of psychological subject vs. psychological predicate. Brassai, on the other hand, provides a syntactic and semantic characterization of the inchoativumbulk structure which is considered basically correct even today. According to Brassai, the inchoativum is a (sequence of) complement(s) in sentence initial position, having a preparatory function and carrying known information, while the bulk is the rest of the sentence, including the verb, and conveying partly or fully new information.

According to Gabelentz, the psychological subject always consists of a single constituent of the sentence, whereas according to Brassai, it can consist of several constituents, including a subordinate clause. Brassai also mentions that Gabelentz only investigates isolated sentences; he does not notice the text-creating role of the psychological subjectpredicate structure, although "speech never serves to express merely single thoughts, but sequences of them, and just as every word, every form has a certain word order value, every sentence, every structure of thought has a given sentence order value" $(1885,30-1)$. Brassai also corrects such minor mistakes of Gabelentz's as his claim that compounds are put together according to the same principles as syntagms, or his claim that a question and an answer constitute a single psychological subject-psychological predicate structure together, with the question representing the subject, the answer representing the predicate.

It also annoys Brassai - with good reason - that Gabelentz claims to perform ethnopsychological language comparison as opposed to the usual language comparison of genealogical purpose. Brassai mentions that, on the one hand, the so-called genealogical language comparison does not 
always give a clue to the genealogy of peoples, and, on the other hand, that the so-called ethnopsychology (Völkerpsychologie) is too obscure a notion to be admitted to science, since there can be greater differences between the mentalities of two Germans than between those of say, a German and a Frenchman. Both Gabelentz and Brassai perform syntactic language comparison, which should also have a role in the comparative linguistic research of "genealogical purpose".

\section{Brassai versus 20th century theories of information structure}

Brassai's theory excels not only Gabelentz's study in clarity and coherence, but also a considerable part of the 20th-century literature of communicative sentence articulation. This literature grew out of Gabelentz's theory; it was his imprecisely defined notions that became implanted in international linguistics, and continued to develop-sometimes in diverse directions. Communicative sentence articulation, or functional sentence perspective was investigated by Herman Paul and Wilhelm Wundt, among others, and between the 1930s and 1970s primarily by the Czech School: Vilém Mathesius, later František Daneš, Jan Firbas, Petr Sgall, and Eva Hajičová. The terms psychological subject and predicate were replaced by theme-rheme, then topic-comment, but there were other designations, too, e.g., topic-focus, and logical subject-logical predicate. There were not only various terms, but also various definitions in use. A group of definitions were based on the division of the sentence into parts carrying known and new information (e.g., in the early Czech School). In other cases Gabelentz's definition survived: about whom or about what something is asserted versus what is asserted about him or about it (Sgall 1967; Sgall et al. 1973; Kuroda 1972-1973). Some theories (e.g., Halliday 1967; Dressler 1974; Kiefer 1977) distinguished both sentence structures. The former interpretation, based on the known-unknown character of the information carried by the sentence parts, acquired a role in transformational generative grammar as the presupposition-focus dichotomy (cf. Chomsky 1970; Jackendoff 1972). The latter interpretation entered generative grammar in the work of Kuroda (1972-1973), via the logical theory of Anton Marty (1918; 1965).

As hypothesized by Brassai, communicative sentence articulation proved to have a significance beyond creating text coherence and expressing pragmatic nuances and emphasis; it has proved to have asometimes decisive - role in the syntactic structure of sentences. The 
various realizations of the universal topic-comment articulation has also formed a basis for syntactic typology (Li-Thompson 1976; É. Kiss 1998). The identification of the topic as a syntactic constituent was in part due to the discovery that certain languages, e.g., Japanese, Korean, the Burmese Lahu and Lisu, unambiguously mark the topic (i.e., Brassai's inchoativum) by a morpheme. The topic features established in this way practically coincided with those identified by Brassai: (i) sentence initial position, (ii) a particular morpheme, or stress and intonation pattern, or relative word order position, or a combination of these, (iii) the given, known, or accessible character of the information conveyed. These languages have also confirmed that the topic is not an indispensable part of the sentence; there are also sentences consisting of a mere comment.

A study by Li and Thompson (1976) typologized the languages of the world on the basis of whether it is the subject or the topic that plays a more decisive role in the syntactic structure of their sentences. In some respect $\mathrm{Li}$ and Thompson's theory is inferior to that of Brassai. In the socalled subject-prominent languages, $\mathrm{Li}$ and Thompson regard only certain rare, highly marked sentence types as topic-comment structures, e.g., in English, the structures derived by Left Dislocation and Topicalization (e.g., As for John, I hate him; John, I hate) - so they do not realize that the unmarked topic-comment structure can be found in these languages, too, only it coincides with the subject-predicate structure. That is, topicprominent and subject-prominent languages differ in the respect that while in the former any sentence constituent can function as topic, in the latter the topic is usually identical with the subject. The subject, however, need not always be a topic in the latter type of languages, either; it can be stressed, in which case the sentence beginning with it has no topic at all. Brassai observed as early as 1860 that "there is a slight difference in quality between the inchoativums of the Semitic and Romance language families. Namely, in the former, the inchoativum can include all kinds of cases, while in the latter, it usually appears in a caseless, i.e., nominative form [...]" $(1860,345)$; that is, "the subjects, i.e., nominatives, of the West-European languages (such as the Romance family, the new German family, English) correspond to the notion of 'inchoativum' and fulfil its role" (ibid., 342).

By now the study of information structure, pioneered by Brassai, has also extended to formal grammatical theories; in fact, it is present in all major theoretical frameworks. Various aspects of information structure have come to represent key areas of syntactic, semantic, prosodic, and 
pragmatic research, examined in innumerable research projects, discussed at innumerable conferences, and studied in innumerable monographs, papers, and doctoral dissertations.

\section{Brassai's Hungarian syntax}

Brassai's Hungarian syntax (worked out most fully in Brassai 1863-1865), the proper, scientific solution of which was the motivation for the elaboration of his general syntactic theory, was not less pioneering in character than the general framework itself.

Brassai was the first person, and the only one in the pre-generative history of Hungarian linguistics to identify an invariant structure in Hungarian sentences, which were generally considered to have an idiosyncratic, "free" word order. He claimed that Hungarian sentences fall into two main units, the inchoativum and the bulk. Their order cannot be reversed, but the inchoativum can be missing, i.e., the sentence can consist merely of a bulk. The two units are separated formally by stress and intonation: the inchoativum is not stressed, while the bulk begins with the highest stress of the sentence accompanied by a high fall (i.e., with a pitch accent).

The inchoativum is represented by one or more complements of the verb that carry known information. If the complement functioning as the inchoativum is nominal, it is usually preceded by the definite article. An indefinite noun can only be an inchoativum in the following case: e.g., "when talking about a hunting event, we would say A hunter fell off the horse, a dog strayed" (1863-1865, 240), i.e., when the indefinite noun has a partitive reading, denoting a member of a known group. As for the bulk, its most highly stressed first position is reserved for the constituent representing the most emphatic element of the semantic contents of the sentence, "which we assume the speaker or listener would ask about" (ibid., 197). (The part of the sentence carrying new information, i.e., the focus, is identified in generative grammar and in the pragmatic literature by a question test even today.) This first position of the bulk is usually filled by a complement, or rarely, by the verb itself. In the former case, the verb occupies the second slot of the bulk. The complement standing before the verb and carrying the sentence stress is called attribute by Brassai. If it is the verb that conveys the most important part of the message in the sentence, the verb will stand first in the bulk and will bear the sentence stress. 
Complements can also stand behind the verb; they are called supplements (egészítvények). If a supplement conveys new information, it will have secondary stress; if it expresses a known idea, i.e., it could just as well have been fronted as an inchoativum, it is unstressed.

So Brassai's model of the Hungarian sentence is as in (3); an example is provided in (4).

(3) (a) sentence $=($ inchoativum +$)$ bulk

(b) bulk $=($ attribute +$)$ verb $(+$ supplements $)$

(4) (a) sentence $=$ [inchoativum A tanító] [bulk meg dicsérte a gyermeket.] the teacher up praised the child 'The teacher praised the child.'

(b) bulk = [attribute meg] [verb dicsérte] [supplement a gyermeket]

What prevented the recognition of this structure both before and after Brassai was presumably the convention of spelling particle + verb complexes as single compound words. It is a key element of Brassai's theory that the verbal particle is an independent adverb, which is on a par with the nominal and adverbial complements of the verb. Brassai has several arguments supporting the claim that the verbal particle is not a verbal prefix but an adverb:

(i) The verbal particle can be used alone as an elliptical sentenceunlike true verbal prefixes in other languages, e.g.: Megetted az ételt? Meg. 'Did you eat the food? I did.'

(ii) Verbal prefixes of other languages that can also be used separately are usually prepositions rather than adverbs.

(iii) Prefixes usually do not have a definite meaning; their interpretation depends on the verbal stem. Hungarian verbal particles, on the other hand, mostly have separate, fixed, definite meanings.

(iv) The meaning of a prefixed verb usually has nothing to do with the meanings of its two components, e.g., bedeuten. In Hungarian, on the other hand, non-compositional particle + verb combinations are rare; most of them were imported as calques during the language reform.

(v) We can only abstract a general rule of word order from the Hungarian sentence if the verbal prefix is analyzed as an independent complement of the verb.

Brassai identified the structure in (3) not only in indicative sentences but in the various kinds of interrogative and imperative sentences, too. 
What is more, he formulated his findings not only in the form of a procedure for the analysis of Hungarian sentences, but also in the form of an 'algorithm' for the production, generation of them. His aim was to establish a set of rules on the basis of which a foreigner can also learn how to produce Hungarian sentences, and, on the other hand, on the basis of which it can be objectively decided if a sentence is good or bad. His algorithm consists of the following major steps:

1. The elements of the sentence denote in part familiar notions, in part notions to be learned.

2. A mechanical means of distinguishing familiar notions from those to be learned is the question which the sentence would answer.

3. The sentence consists of an inchoativum and a bulk, or only of a bulk. The initial element of the bulk is emphasized.

4. The elements to be learned must all be placed in the bulk.

5 . The elements to be learned are usually accented.

6 . The verb is only accented if it represents the only notion to be learned.

7. One of the complements to be learned can precede the verb as an attribute; the rest must follow the verb as supplements.

8. If the verb has a single complement to be learned, and the verb is either known, or has a vague meaning, the complement occupies the preverbal attribute position.

9. If the verb and all the complements convey important information to be learned, the complements are put into the postverbal supplement position.

10. The known complements can be placed either in the inchoativum, or in the bulk.

11. Complements expressing notions which serve as an indispensable basis or condition of the interpretation of the bulk must be placed in the inchoativum.

12. Those which have a looser relation to the bulk can appear among the supplements.

Brassai's algorithmic approach anticipated, in a certain respect, the programme of generative grammar. No wonder that the attempt at outlining a Hungarian generative syntax led to the rediscovery of Brassai's long forgotten results (see É. Kiss 1977). 


\section{Brassai's Hungarian sentence structure versus that of generative syntax}

The structures that various generative syntactic descriptions assign to the Hungarian sentence differ from Brassai's only in minor respects. In the current descriptions of Hungarian sentence structure, the unit corresponding to Brassai's attribute is not a sister of the verb and the postverbal complements but is the sister of a node dominating the verb and the postverbal complements, for example:

(5)

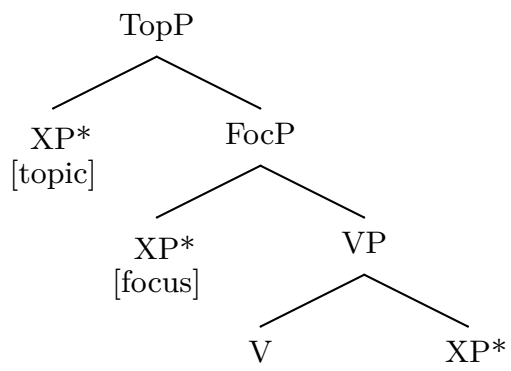

The iterable XP immediately domined by the TopP node is identified as the topic of the sentence, whereas the XP dominated by the FocP node is analyzed as the focus. The topic and focus positions are generated empty, and are assumed to be filled by complements of the V.

It is furthermore assumed that a stress rule assigns a pitch accent (to be denoted below by an accent mark) to the first major category dominated by FocP.

Thus, a Hungarian speaker has the following options in organizing a verb with two complements, e.g., eszi Péter az almát 'eats Peter the apple', into a sentence:

(i) He does not perform either Focusing or Topicalization, in which case the pitch accent will fall on the verb:

(6) (a) 'Eszi Péter az almát.

(b) 'Eszi az almát Péter.

(The order of maximal major categories is free in the VP.) 
(ii) He performs Focusing, but no Topicalization:

(7) (a) 'Péter eszi az almát.

(b) Az'almát eszi Péter.

(iii) He performs Topicalization, but no Focusing:

(8) (a) Péter 'eszi az almát.

(b) Az almát 'eszi Péter.

(iv) He performs both Focusing and Topicalization:

(9) (a) Péter az'almát eszi.

(b) Az almát 'Péter eszi.

These would be the variants produced by Brassai's algorithm, too. He would also assign a similar structure to sentences containing a particle verb. Brassai recognized that the verbal particle, regarded as part of the verb in traditional grammars, is an independent syntactic unit, a potential filler of the attribute position. In the presence of a focused complement, the particle stays behind the verb, which Brassai interprets as evidence of their complementary distribution:

(10) (a) Péter 'meg ette az almát.

(b) Péter az'almát ette meg.

(c) Az almát 'Péter ette meg.

Some recent versions of Hungarian generative syntax, e.g., Brody (1990), regard the complementary distribution of the verbal particle and a focused complement in preverbal position as an epiphenomenon. According to Brody, the focussed complement is dominated by a higher projection than that dominating the verbal particle; the focus projection has an empty head which attracts the $\mathrm{V}$ into focus-adjacent position across the particle (11).

A syntactic phenomenon which may slightly modify the structure in $(5) /(11)$, and which Brassai could only handle with difficulties, is quantifier-raising to the left edge of the bulk (a FocP or PredP). Q-raising is an overt operation in Hungarian, yielding an additional constituent bearing a pitch accent in front of the focus or verbal particle (see $(12 \mathrm{a}, \mathrm{b})$ ). 
(11)

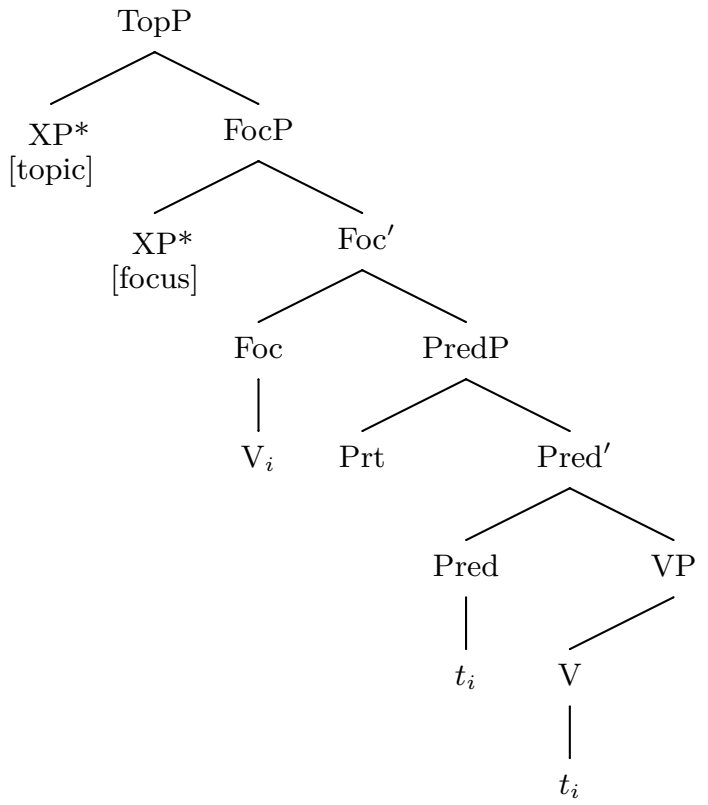

(12) (a) [TopP Az almát [PredP 'minden gyerek [PredP 'meg ette]]] the apple-acc every child prt ate

'Every child ate the apple.'

(b) [TopP A gyerek [PredP 'mindkét almát [PredP 'meg ette]]] the child both apple-acc prt ate

'The child ate both apples.'

In the pre-generative history of Hungarian linguistics, Brassai's forgotten theory came closest to the idea of generating all and only the grammatical permutations of a verb and its complements. Research in the past three decades has made Brassai's sentence model more precise, finer-tuned; nevertheless, it has not questioned the correctness of his basic approach.

\section{References}

Brassai, Sámuel 1852. Tapogatódzások a magyar nyelv körül [Exploring the Hungarian language]. In: Pesti Napló 1852: № 802, 803; 1853: 861, 862, 865, 876, 877, 878, 885.

Brassai, Sámuel 1860. A magyar mondat I [The Hungarian sentence I]. In: Magyar Akadémiai Értesítő. A Nyelv- és Széptudományi Osztály Közlönye 1 : 279-399. 
Brassai, Sámuel 1863-1865. A magyar mondat II [The Hungarian sentence II]. In: Magyar Akadémiai Értesítő. A Nyelv- és Széptudományi Osztály Közlönye 3: 3-128, 173-409.

Brassai, Sámuel 1874. Laelius. Hogyan kell és hogyan nem kell magyarázni az iskolában a latin auktorokat? [Laelius. How to explain and how not to explain the Latin authors at school?] Stein, Kolozsvár.

Brassai, Sámuel 1885. A mondat dualismusa [The dualism of the sentence]. Értekezések a Magyar Tudományos Akadémia Nyelv- és Széptudományi Osztály Köréből 12.

Brody, Michael 1990. Some remarks on the focus field in Hungarian. In: UCL Working Papers in Linguistics 2:201-26.

Chomsky, Noam 1970. Deep structure, surface structure, and semantic interpretation In: Roman Jakobson and Shiego Kawamoto (eds): Studies in general and oriental linguistics, 52-91. TEC Corporation for Language Research, Tokyo.

Daneš, František (ed.) 1974. Papers on Functional Sentence Perspective. Academia, Prague.

Daneš, František et al. 1974. Zur Terminologie der funktionalen Satzperspektive. In: Daneš $(1974,217-22)$.

Dressler, Wolfgang 1974. Funktionelle Satzperspektive und Texttheorie. In: Daneš (1974, 87-105).

Fillmore, Charles J. 1968. The case for case. In: Emmon Bach and Robert T. Harms (eds): Universals in linguistic theory, 1-88. Holt, Rinehart and Winston, New York.

Firbas, Jan 1974. Some aspects of the Czechoslovak approach to problems of functional sentence perspective. In: Daneš $(1974,11-37)$.

Gabelentz, Georg von der 1869. Ideen zu einer vergleichenden Syntax - Wort- und Satzstellung. In: Zeitschrift für Völkerpsychologie und Sprachwissenschaft $6: 376-$ 84 .

Gabelentz, Georg von der 1875. Weiteres zur vergleichenden Syntax. In: Zeitschrift für Völkerpsychologie und Sprachwissenschaft $8: 129-65$.

Halliday, Michael A. K. 1967. Notes on transitivity and theme in English II. In: Journal of Linguistics $3: 199-244$.

Jackendoff, Ray 1972. Semantic interpretation in generative grammar. MIT Press, Cambridge MA.

É. Kiss, Katalin 1977. Topic and Focus in Hungarian syntax. In: Montreal Working Papers in Linguistics $8: 1-42$.

É. Kiss, Katalin 1981. Syntactic relations in Hungarian, a "free" word order language. In: Linguistic Inquiry $12: 185-215$.

É. Kiss, Katalin 1998. Discourse-configurationality in the languages of Europe. In: Anna Siewierska (ed.): Constituent order in the languages of Europe, 621-729. Mouton de Gruyter, Berlin \& New York.

Kiefer, Ferenc 1977. Functional sentence perspective and presuppositions, In: Acta Linguistica Hungarica $27: 83-109$. 
Kiefer, Ferenc 2005. Brassai Sámuel és a XIX. század nyelvtudománya [Sámuel Brassai and the linguistics of the 19th century]. In: János Péntek (ed.): A nyelvész Brassai élö öröksége [The legacy of Brassai, the linguist] (Erdélyi Tudományos Füzetek 256), 6-10. Erdélyi Múzeum Egyesület, Kolozsvár.

Kuroda, Sige-Yuki 1972-1973. The categorical and the thetic judgement: Evidence from Japanese syntax. In: Foundations of Language $9: 153-85$.

Li, Charles N.-Sandra Thompson 1976. Subject and topic: A new typology of languages. In: Charles Li (ed.): Subject and topic, 457-90. Academic Press, New York.

Marty, Anton 1918. Gesammelte Schriften II. Band 1: Abteilung. Max Niemeyer, Halle.

Marty, Anton 1965. Psyche und Sprachstruktur. Francke, Bern.

Mathesius, Vilém 1929. Zur Satzperspektive im modernen Englisch. In: Archiv für die neueren Sprachen und Literaturen $155: 202-10$.

Mathesius, Vilém 1939. O tak zvaném aktuálním členění věty. In: Slovo a slovesnost $5: 171-4$.

Sgall, Petr 1967. Functional sentence perspective in generative description. In: Prague Studies in Mathematical Linguistics 2:203-25.

Sgall, Petr-Eva Hajičová - Eva Benešová 1973. Topic/Focus and generative semantics. Scriptor, Kronberg-Taunus.

Weil, Henri 1844. De l'ordre des mots dans les langues anciennes comparées aux langues modernes. Paris. 